\title{
Effect of Nanosheet Surface Structure of Titanium Alloys on Cell Differentiation
}

\author{
Satoshi Komasa, ${ }^{1}$ Tetsuji Kusumoto, ${ }^{2}$ Yoichiro Taguchi, ${ }^{3}$ Hiroshi Nishizaki, ${ }^{1}$ \\ Tohru Sekino, ${ }^{4}$ Makoto Umeda, ${ }^{3}$ Joji Okazaki, ${ }^{1}$ and Takayoshi Kawazoe ${ }^{2}$ \\ ${ }^{1}$ Department of Removable Prosthodontics and Occlusion, Osaka Dental University, 8-1 Kuzuha-hanazono-cho, \\ Hirakata, Osaka 573-1121, Japan \\ ${ }^{2}$ Department of Fixed Prosthodontics and Occlusion, Osaka Dental University, 8-1 Kuzuha-hanazono-cho, \\ Hirakata, Osaka 573-1121, Japan \\ ${ }^{3}$ Department of Periodontology, Osaka Dental University, 8-1 Kuzuha-hanazono-cho, Hirakata, Osaka 573-1121, Japan \\ ${ }^{4}$ The Institute of Scientific and Industrial Research, Osaka University, 8-1 Mihogaoka, Ibaraki, Osaka 567-0047, Japan
}

Correspondence should be addressed to Satoshi Komasa; komasa-s@cc.osaka-dent.ac.jp

Received 12 June 2014; Revised 14 September 2014; Accepted 14 September 2014; Published 10 November 2014

Academic Editor: Zhongkui Hong

Copyright (C) 2014 Satoshi Komasa et al. This is an open access article distributed under the Creative Commons Attribution License, which permits unrestricted use, distribution, and reproduction in any medium, provided the original work is properly cited.

\begin{abstract}
Titanium alloys are the most frequently used dental implants partly because of the protective oxide coating that spontaneously forms on their surface. We fabricated titania nanosheet (TNS) structures on titanium surfaces by $\mathrm{NaOH}$ treatment to improve bone differentiation on titanium alloy implants. The cellular response to TNSs on Ti6Al4V alloy was investigated, and the ability of the modified surfaces to affect osteogenic differentiation of rat bone marrow cells and increase the success rate of titanium implants was evaluated. The nanoscale network structures formed by alkali etching markedly enhanced the functions of cell adhesion and osteogenesis-related gene expression of rat bone marrow cells. Other cell behaviors, such as proliferation, alkaline phosphatase activity, osteocalcin deposition, and mineralization, were also markedly increased in TNS-modified Ti6Al4V. Our results suggest that titanium implants modified with nanostructures promote osteogenic differentiation, which may improve the biointegration of these implants into the alveolar bone.
\end{abstract}

\section{Introduction}

There has been a concerted effort among materials scientists and clinicians worldwide to improve the performance of dental implants, with the aim of facilitating their integration into hard and soft tissues and/or extending their range of applications. The surface characteristics of an implant material affect its rate and extent of osseointegration [1]. Vandrovcová et al. [2] recently reviewed the growing evidence demonstrating that surface-modified materials are highly effective for adhesion, growth, and osteogenic differentiation of cells.

Osteogenic cells are known as anchorage-dependent cells. Accordingly, it is necessary to enhance early bone differentiation of mesenchymal cells and improve osseointegration on titanium surfaces [3-8]. A previous study showed that nanostructural modification can accelerate hard-tissue engineering through increased initial cell attachment to the surface [9].
Surface modification may allow the osseointegration period of any implant material to be shortened. Surface roughness has been shown to influence the initial cellular response, for example, the differentiation of human osteoblastic MG63 cells through $\alpha 5$ integrin interactions [10]. Another study found that the degree of osseointegration can be changed by controlling the size of nanostructures formed on titanium alloy surfaces [11].

In this study, nanostructures similar to the $\mathrm{TiO}_{2}$ nanotubes formed by titanium deposition by $\mathrm{TiO}_{2}$ sputtering [12] named titanium nanosheets (TNS) are formed on titanium alloy surfaces. Recently, it was shown that $\mathrm{TiO}_{2}$ nanotube and TNS structures can be formed on titanium metal surfaces by treatment in $10 \mathrm{M} \mathrm{NaOH}$ aqueous solution at $30^{\circ} \mathrm{C}$ [13]. Treatment with $\mathrm{NaOH}$ aqueous solution is known to produce a rough, nanoscale surface [14]. A previous study reported that TNS produced by chemical processing promoted the 


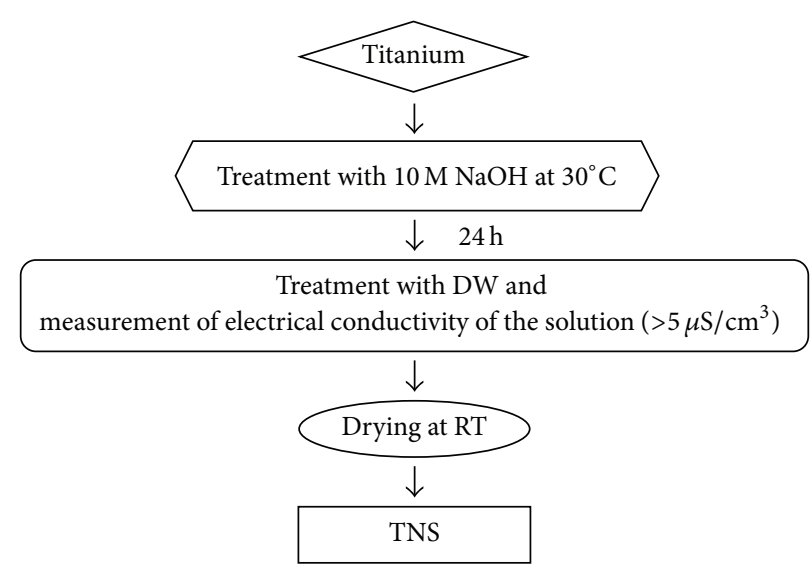

FIGURE 1: TNS deposition process.

osteogenic differentiation of rat bone marrow (RBM) cells [13]. The surface properties and structures of materials play important roles in the adsorption of proteins, which might influence cell behavior. However, the structure of TNS is unclear and the manner in which this structure influences bone differentiation must be evaluated for its application as an advanced implant material.

Titanium alloys are the most frequently used metallic materials for medical implants partly because of the protective oxide coating that spontaneously forms on their surface. Although titanium alloys exhibit excellent overall corrosion properties, metal ions released in physiological environments are still a concern. It has been suggested that the physicochemical and dielectric properties of the oxide film play important roles in determining implant biocompatibility [15]. Kim et al. [16] showed that $\mathrm{NaOH}$ treatment caused $\mathrm{Ti}-\mathrm{OH}$ groups to form on the sodium titanate layer of the titanium surface. However, it is not yet clear how alloying species such as aluminum $(\mathrm{Al})$ and $\mathrm{V}$ affect the bone differentiation of RBM cells following $\mathrm{NaOH}$ treatment.

The aims of the present study are to investigate the TNS structure of Ti6Al4V alloy and to evaluate the ability of this modified surface to affect osteogenic differentiation of RBM cells to increase the success rate of titanium implants. We prepare TNS structures on disks by $\mathrm{NaOH}$ treatment, investigate their morphology, and assess their biocompatibility.

\section{Materials and Methods}

2.1. Sample Preparation. Titanium alloy samples treated with $\mathrm{NaOH}$ to form TNSs on their surfaces were used as the experimental material. Unprocessed titanium alloy disks (Ti6Al4V) were used as the control group. Figure 1 outlines the process followed to produce TNSs. Ti6Al4V disks $(15 \mathrm{~mm}$ diameter) were punched from sheets of $1 \mathrm{~mm}$ thick alloyed titanium (Daido Steel, Osaka, Japan). The disks were immersed in $10 \mathrm{Maq}$. $\mathrm{NaOH}$ and maintained at $30^{\circ} \mathrm{C}$ for $24 \mathrm{~h}$. The solution in each flask was replaced with distilled water $(200 \mathrm{~mL})$ until the solution reached a conductivity of $5 \mu \mathrm{S} / \mathrm{cm}$. Samples were then dried at room temperature.

2.2. Characterization of Materials. The surface topography of samples was qualitatively evaluated by scanning electron microscopy (SEM, S-4000, Shimadzu, Kyoto, Japan) and scanning probe microscopy (SPM; SPM-9600, Shimadzu). The composition of the coating was analyzed by X-ray photoelectron spectroscopy (XPS; Kratos Analytical Axis ultra DLD electron spectrometer, Kratos Instruments, Manchester, UK) using a monochromatic $\mathrm{Al} \mathrm{K} \alpha$ X-ray source. Each sample was etched with argon ions for 2 min (evaporation rate $5 \mathrm{~nm} / \mathrm{min}$ ) to remove surface contaminants. Contact-angle measurements were performed using a video contact-angle measurement system (VSA 2500 XE, AST Products, Tokyo, Japan) at room temperature. Ultrapure water was used in contact-angle measurements.

2.3. Protein Adsorption Assay. Bovine serum albumin (BSA) fraction V (Pierce Biotechnology) was used as a model protein. Protein solution $(300 \mu \mathrm{L}, 1 \mathrm{mg} / \mathrm{mL}$ protein in saline) was pipetted onto each sample. After incubation for $1,3,6$, or $24 \mathrm{~h}$ at $37^{\circ} \mathrm{C}$, nonadherent proteins were removed and mixed with bicinchoninic acid (Pierce Biotechnology) at $37^{\circ} \mathrm{C}$ for $1 \mathrm{~h}$. The amount of removed albumin and the total amount of albumin inoculated were quantified using a microplate reader at $562 \mathrm{~nm}$. The rate of albumin adsorption was calculated as the percentage of albumin adsorbed on samples relative to the total amount of albumin in solution.

2.4. Cell Culture. RBM cells were isolated from the femurs of 7-week-old Sprague-Dawley rats. This study was performed under the Guidelines for Animal Experimentation at Osaka Dental University (Approval number 11-03038). Briefly, rats were euthanized using $4 \%$ isoflurane, and the bones were aseptically excised from the hind limbs. The proximal end of the femur and the distal end of the tibia were clipped. A 21-gauge needle (Terumo, Tokyo, Japan) was inserted into the hole in the knee joint of each bone, and the marrow was flushed from the shaft with culture medium (Eagle's minimal essential medium; Wako Pure Chemical Industries, Ltd., Osaka, Japan) supplemented with $10 \%$ fetal bovine serum (FBS; Invitrogen, Life Technologies Co., Carlsbad, CA, USA), penicillin $(500 \mathrm{U} / \mathrm{mL}$ ) (Cambrex Bio Science Walkersville Inc., Walkersville, MD, USA), streptomycin $(500 \mu \mathrm{g} / \mathrm{mL})$ (Cambrex Bio Science Walkersville Inc.), and Fungizone $(1.25 \mu \mathrm{g} / \mathrm{mL})$ (Cambrex Bio Science Walkersville Inc.). 


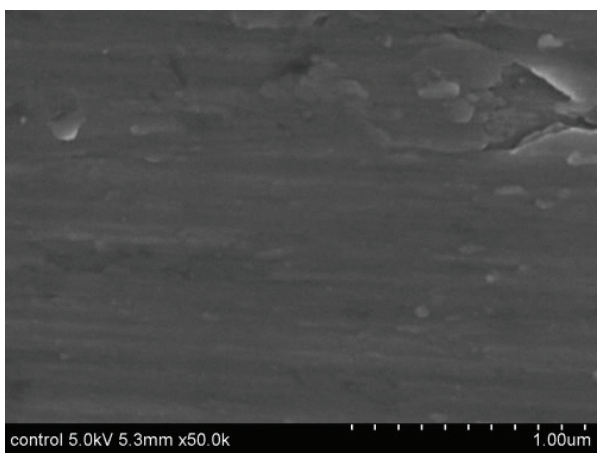

(a) Control

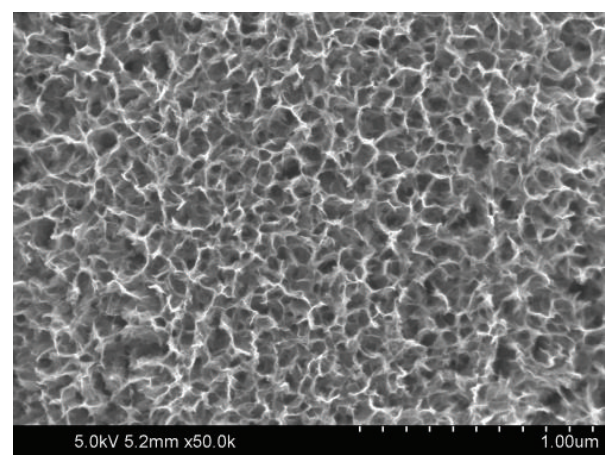

(b) TNS

FIGURE 2: SEM images of the (a) untreated (control) and (b) treated (TNS) titanium alloy surface. The control sample exhibited relatively smooth surface features. A nanosheet structure formed upon $\mathrm{NaOH}$ treatment of the titanium alloy surface.

The resulting marrow pellet was dispersed by trituration, and the cell suspensions from all bones were combined in a centrifuge tube. RBM cells were cultured in $75 \mathrm{~cm}^{2}$ culture flasks (Falcon, Becton Dickinson Labware, NJ, USA) in culture medium.

At confluence, cells were removed from flasks by trypsinization, washed twice with PBS, resuspended in culture medium, and seeded at a cell density of $4 \times 10^{4}$ cells $/ \mathrm{cm}^{2}$ into 24-well tissue culture plates (Falcon) containing test or control titanium disks. The cells were cultured at $37^{\circ} \mathrm{C}$ in a humidified 5\% $\mathrm{CO}_{2} / 95 \%$ air atmosphere.

2.5. Cell Adhesion and Proliferation. Cell adhesion was measured using the CellTiter-Blue Cell Viability Assay (Promega, Madison, WI, USA) according to the manufacturer's protocol. RBM cells were seeded on the samples at a density of $4 \times$ $10^{4}$ cells $/ \mathrm{cm}^{2}$ and allowed to attach for $1,3,6,24$, and $72 \mathrm{~h}$. At each prescribed time point, nonadherent cells were removed by rinsing with PBS. CellTiter-Blue Reagent $(50 \mu \mathrm{L})$ and PBS $(250 \mu \mathrm{L})$ were then added to each well. After incubation at $37^{\circ} \mathrm{C}$ for $1 \mathrm{~h}$, the solution was removed from the 24-well tissue culture plates (Falcon) and $100 \mu \mathrm{L}$ was added to a new 96-well tissue culture plate (Falcon). The OD560/590 of the remaining solution was measured. The difference between the two optical densities was defined as the proliferation value.

2.6. Real-Time PCR Analysis. After 3 days of culture, the total RNA was extracted from the cells and cDNA was synthesized from $1 \mu \mathrm{g}$ of RNA using a High-Capacity cDNA Archive Kit (Applied Biosystems Inc., Foster City, CA, USA). Runx2 mRNA expression was investigated by real-time reverse transcriptase-polymerase chain reaction (RT-PCR) using a StepOne Plus Real-Time RT-PCR System (Applied Biosystems). To each well of a Fast 96-well Reaction Plate $(0.1 \mathrm{~mL}$ well volume; Applied Biosystems) was added Taqman Fast Universal PCR Master Mix $(10 \mu \mathrm{L}), 1 \mu \mathrm{L}$ of the primer probe set (20x Taqman Gene Expression Assays: Applera ordering number: Rss330360-m1Gadphs, Rss339198-m1runx2), sample cDNA $(2 \mu \mathrm{L})$, and diethylpyrocarbonate-treated water (Nippongene, $7 \mu \mathrm{L}$ ). The plate was subjected to 40 reaction cycles of $95^{\circ} \mathrm{C}$ for $1 \mathrm{~s}$ and $60^{\circ} \mathrm{C}$ for $20 \mathrm{~s}$. The reactive gene expression rate was calculated employing the $\Delta \Delta \mathrm{Ct}$ method
[17] for each group assuming the gene expression rate of the negative control group.

2.7. ALP Activity. After 7 or 14 days of culture, cells were washed with PBS, lysed with Triton X-100 (Sigma, St. Louis, MO, USA, $0.2 \%, 200 \mu \mathrm{L}$ ), and the lysate was transferred to a microcentrifuge tube containing a $5 \mathrm{~mm}$ hardened steel ball. Tubes were agitated on a shaker (Mixer Mill Type MM 301, Retsh Gmbh \& Co., Haan, Germany) at $29 \mathrm{~Hz}$ for $20 \mathrm{~s}$ to homogenize each sample. ALP activity was measured using the Alkaline Phosphatase Luminometric ELISA Kit (Sigma) according to the manufacturer's protocol. The reaction was terminated with $3 \mathrm{~N} \mathrm{NaOH}$ to a final concentration of $0.5 \mathrm{~N} \mathrm{NaOH}$ and $\mathrm{p}$-nitrophenol production was measured by absorbance at $405 \mathrm{~nm}$ using a 96-well microplate reader (SpectraMax M5, Molecular Device Inc., Sunnyvale, CA, USA). DNA content was measured using the PicoGreen dsDNA Assay Kit (Invitrogen) according to the manufacturer's protocol. To normalize ALP activity, the amount of ALP was normalized to the amount of DNA in the cell lysate.

2.8. Osteocalcin ELISA Analysis. The sandwich enzyme immunoassay used in this study is specific for rat osteocalcin $(\mathrm{OCN})$ and can measure its levels directly in cell culture supernatant after 21 or 28 days of culture. The OCN levels in cell-culture supernatant were measured using a commercial ELISA kit (Rat Osteocalcin ELISA Kit DS, DS Pharma Biomedical Co., Ltd., Osaka, Japan) according to the manufacturer's instructions.

2.9. Mineralization. Calcium deposited in the extracellular matrix was measured after dissolution with $10 \%$ formic acid. The amount of calcium was quantified using a Calcium $E$ test Kit (Wako Pure Chemical Industrials Ltd.). After 21 or 28 days of culture, Calcium E-Test reagent $(1 \mathrm{~mL})$ and kit buffer $(2 \mathrm{~mL})$ were added to collected medium $(50 \mu \mathrm{L})$, and the absorbance of the reaction products was measured at $610 \mathrm{~nm}$ using a 96-well microplate reader (SpectraMax M5). The concentration of calcium ions was calculated from the absorbance value relative to a standard curve.

2.10. Statistical Analysis. All experiments were performed in triplicate. All data are described as the mean \pm standard 


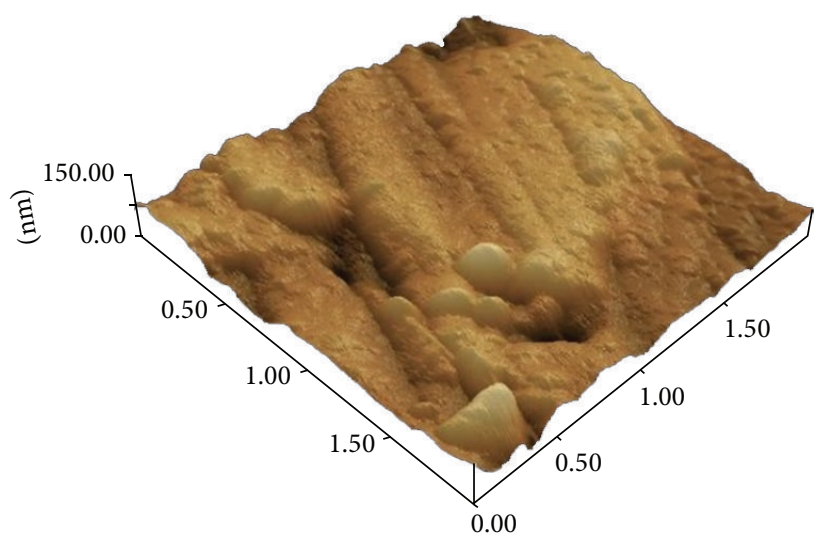

$2.00 \times 2.00(\mu \mathrm{m}) Z \quad 0.00-150.00(\mathrm{~nm})$

(a) Control

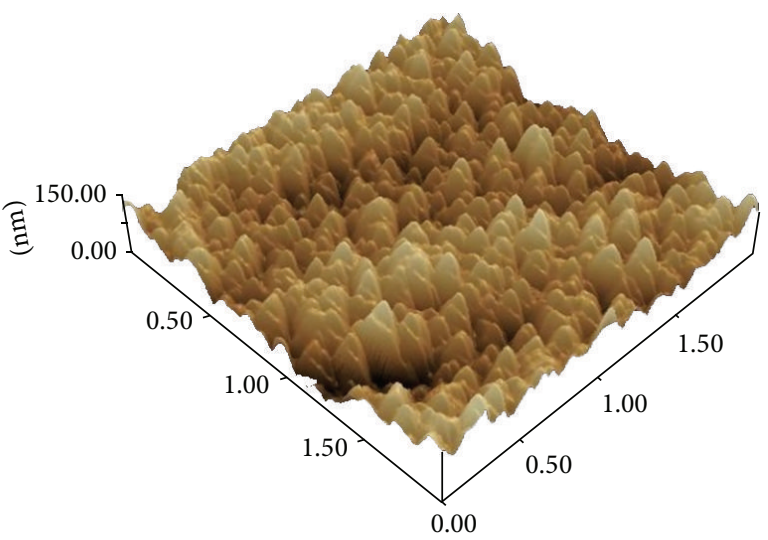

$2.00 \times 2.00(\mu \mathrm{m}) Z$ Z $0.00-150.00(\mathrm{~nm})$

(b) TNS

FIGURE 3: SPM images of (a) untreated (control) and (b) treated (TNS) titanium alloy samples.

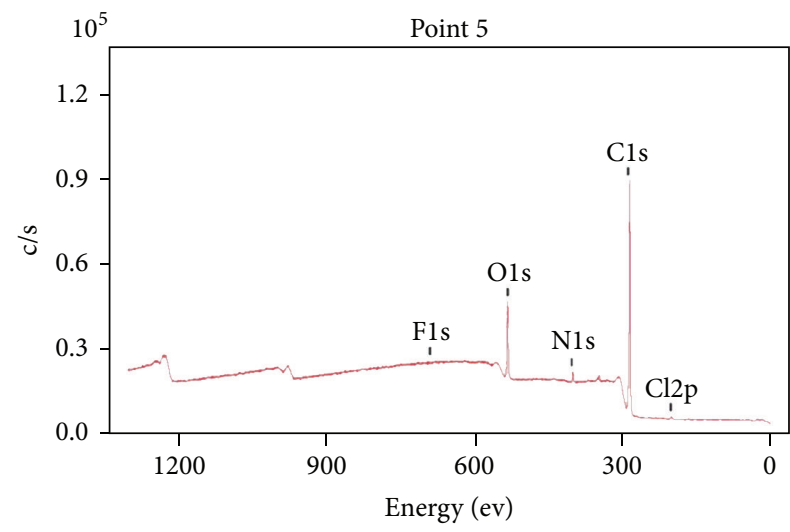

(a)
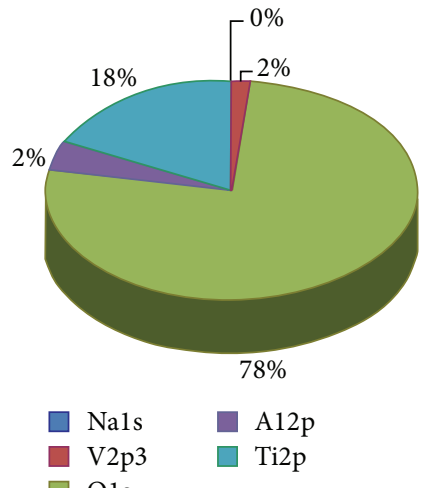

(c)

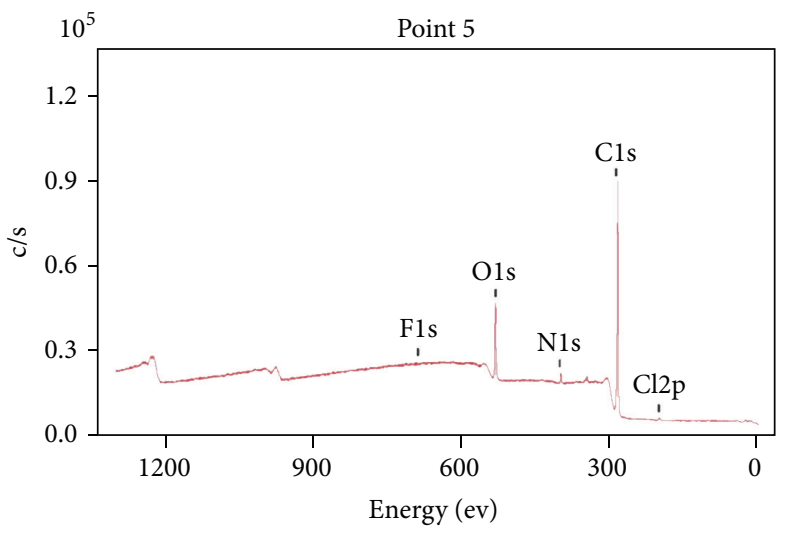

(b)

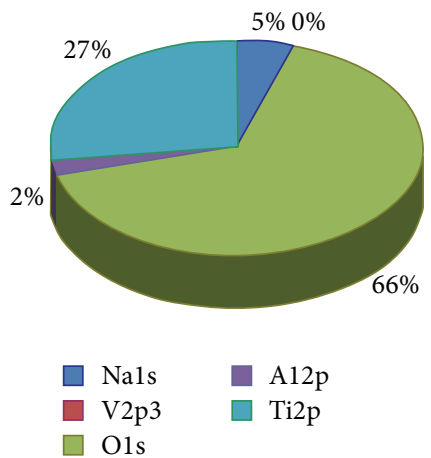

(d)

FIgURE 4: (a, b) Wide-range XPS images and $(c, d)$ atomic concentration of $(a, c)$ treated (TNS) and (b, d) control titanium alloy surfaces.

deviation. In all analyses, statistical significance was determined by paired two-tailed Student's $t$-test. A $P$ value of 0.05 or less was considered to indicate statistical significance.

\section{Results}

3.1. Sample Preparation. SEM of the Ti6Al4V surfaces after modification in $\mathrm{NaOH}$ at $30^{\circ} \mathrm{C}$ revealed that a nanoscale network structure formed. Figure 2 shows SEM images of the relatively smooth surface of the untreated Ti6Al4V and the nanoscale network structure of the chemically treated titanium alloy surface of the test group (labeled TNS), similar to that observed by Kasuga et al. [12]. The surface morphology and roughness of the TNS samples were examined by SPM; the results are shown in Figure 3. Porous network structures were observed in the treated samples. The surface roughness 


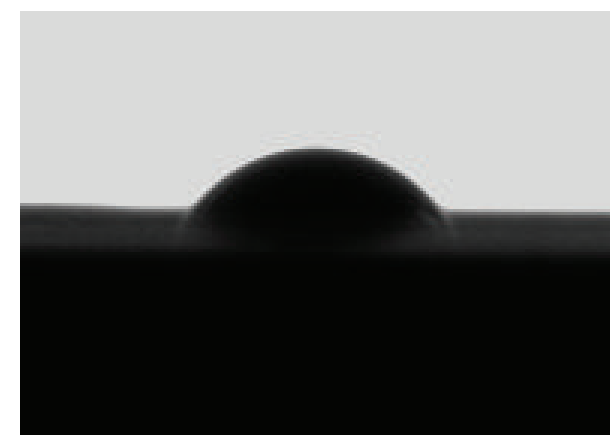

(a) Control

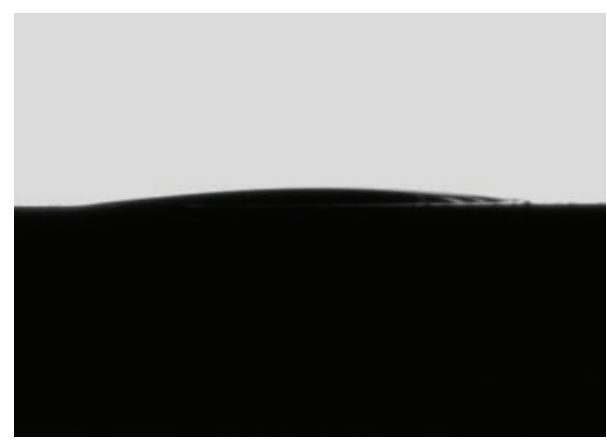

(b) TNS

FIgURE 5: Cross-sectional view of a water droplet on the surface of (a) control and (b) treated (TNS) titanium alloy samples.

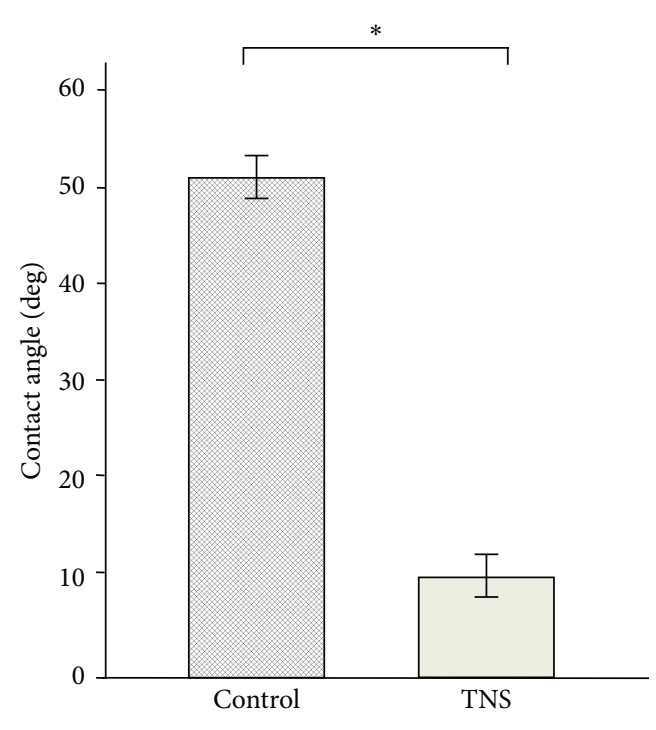

Figure 6: Contact angle of a water droplet on the surface of control and treated (TNS) titanium alloy samples.

(Ra) of the TNS and control groups was 19.9 and $47.8 \mathrm{~nm}$, respectively. XPS revealed that Ti6Al4V released its alloying species of $\mathrm{Al}$ and $\mathrm{V}$ during $\mathrm{NaOH}$ treatment (Figures 4(c) and $4(\mathrm{~d})$ ). No $\mathrm{V}$ was detected on the modified surfaces of the treated alloy disks and screw post (Figures 4(a) and 4(b)). In contrast, the contents of $\mathrm{Ti}, \mathrm{Na}$, and $\mathrm{O}$ were hardly affected by alkali treatment. Cross-sectional views of water droplets on the surfaces of treated and control disks and their contact angles are depicted in Figure 5. A marked difference was found between the contact angles measured for the test and control disks (Figure 6).

3.2. Protein Adsorption. The amount of BSA protein adsorbed on the surface of the samples after $1,3,6$, or $24 \mathrm{~h}$ of incubation was assayed (Figure 7). More protein was adsorbed onto the alkali-treated samples than the control ones.

3.3. Cell Adhesion and Proliferation. Cell adhesion as well as proliferation on the disks after $1,3,6,24$, and $72 \mathrm{~h}$ of incubation was assessed (Figure 8). There were significant differences in cell adhesion and proliferation between alkalitreated and control samples after 1, 3, 6, 24, and $72 \mathrm{~h}$.

3.4. Run $x 2$ mRNA Expression. Run $x 2$ is a transcription factor involved in the early stages of osteogenic differentiation. As shown in Figure 9, Runx2 activity was significantly higher in the test group using treated alloy with TNSs than in the control group after 3 days of culture.

3.5. Alkaline Phosphatase Activity. Cell differentiation was assessed by measuring the activity of the differentiation marker ALP in the test and control groups after 7 and 14 days. At both time points, ALP activity was significantly higher in the cells of the test group compared with that in the cells of the control group (Figure 10).

3.6. Osteocalcin Production. Figure 11 shows the production of OCN in the test and control groups after 21 and 28 days. The content of OCN in the supernatant of the test group was significantly higher than that in the supernatant of the control group.

3.7. Mineralization. Calcium deposition in the extracellular matrix of RBM cells in the test and control groups after 21 and 28 days is illustrated in Figure 12. Ca deposition was cumulative in the culture wells, so that measured levels normally increased with exposure time. Significantly more calcium was deposited by cells in the test group after both periods than by cells in the control group.

\section{Discussion}

This study investigated whether RBM cells responded differently to titanium alloy implants that had undergone chemical surface modification compared with those that had not. We found that the initial adhesion of cells and expression of the Runx2 transcription factor and RBM cell differentiation markers such as ALP and OCN were elevated in samples containing a TNS-modified titanium alloy disk compared with those containing an unmodified, polished titanium alloy disk. We also found that calcium deposition in the extracellular 

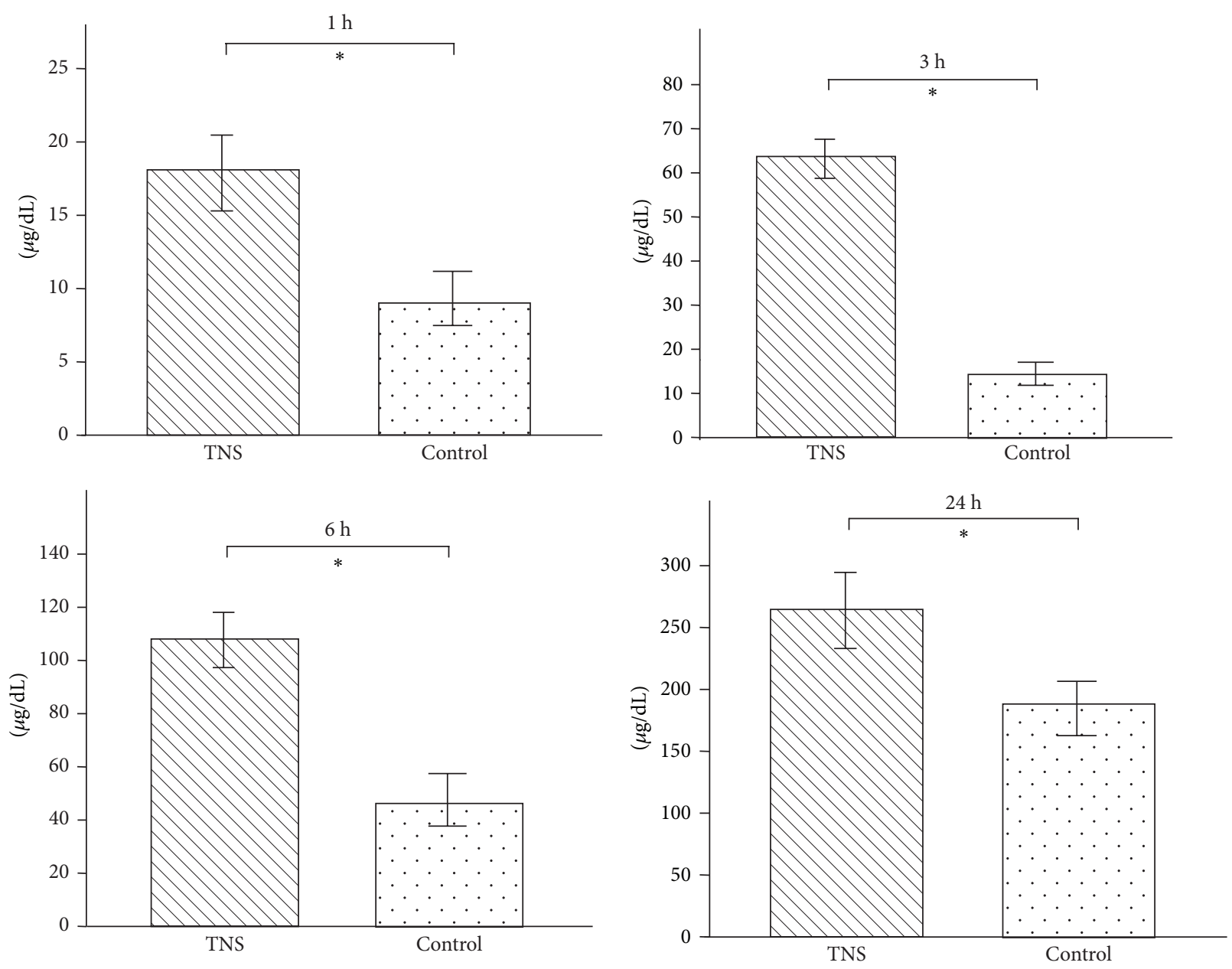

FIGURE 7: Initial adhesion of serum albumin to control and treated (TNS) titanium alloy samples.

matrix of the RBM cells was increased in the presence of a TNS-modified disk compared with that determined for the unmodified control disks. Our results suggest that a TNS structure on titanium alloy promotes RBM cell adhesion, differentiation, and activation, which augments calcium deposition.

The surface properties of dental implants have long been recognized as critical factors for achieving clinical success [18-21]. The topographical properties of nanostructures on titanium alloy surfaces play important roles in modulating cell responses at the implant-tissue interface, which can have a large effect on tissue integration with the implant [22]. Recently, we showed that $\mathrm{TiO}_{2}$ nanotubes and TNSs could be formed on titanium metal surfaces by treatment in $10 \mathrm{M} \mathrm{NaOH}$ aqueous solution at $30^{\circ} \mathrm{C}$ [14], and we used this method here to prepare TNS-modified disks. Perla and Webster [14] suggested that TNSs on titanium surfaces lead to the regulation of osteogenic differentiation of bone marrow cells and enhance mineralization. Our results demonstrate that the TNS-modified titanium alloy disks were more hydrophilic and exhibited markedly improved wettability compared with unmodified ones. Better understanding of the surface roughness and topography of modified titanium alloy surfaces is needed to assess their wettability. Ra is a commonly used height parameter to describe implant surface roughness. $\mathrm{Ra}$ of the TNS-modified titanium alloy surface was $19 \mathrm{~nm}$, which was smaller than that of the untreated titanium alloy surface. The contact angles of the alkali-treated titanium alloy disks gradually decreased compared with those of the control group, which suggests that the wettability of the surface of the test group was decreased by $\mathrm{NaOH}$ treatment. Xing and Fujino and colleagues showed that a surface roughness between 13 and $16 \mathrm{~nm}$ was optimal for RBM cell culture $[23,24]$. The nanonetwork structure formed on the titanium alloy disks here is similar to the hierarchical structure reported by Zhao and coworkers [25]. In their work, hierarchical nanotextured titanium alloy surface topographies with titania nanostructures that mimicked the hierarchical structure of bone tissues were produced by etching followed by anodization. Natural tissues are hierarchical structures of nanoscale building blocks assembled in an organized manner. Hierarchical structures composed of nanocomponents may provide a more suitable surface topography for bone marrow cell functions than simpler structures because they can better mimic the structure of natural tissues. In this study, XPS analysis revealed that Ti6Al4V released its alloying species of 

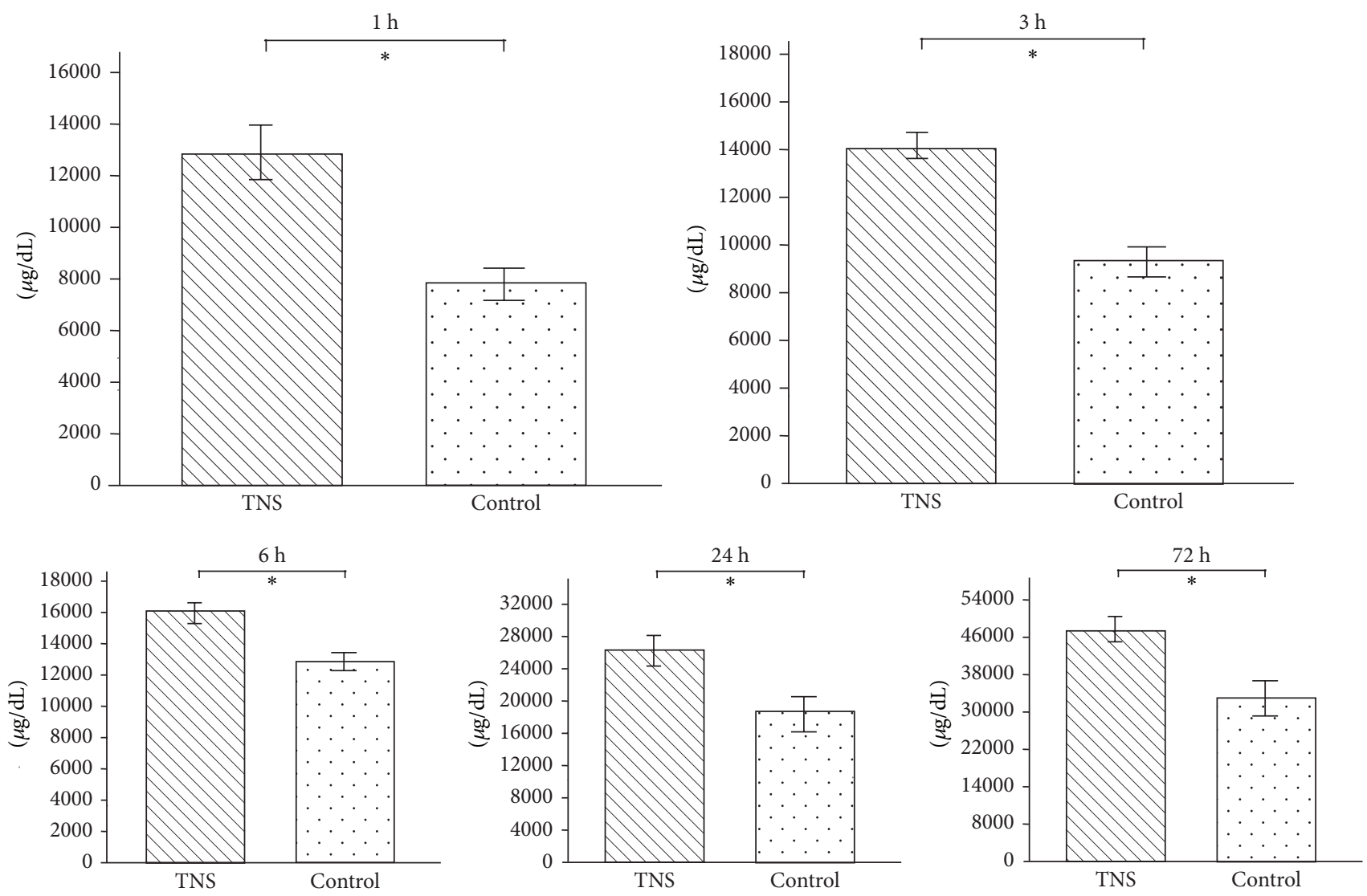

FIGURE 8: Initial adhesion of RBM cells to control and treated (TNS) titanium alloy samples.

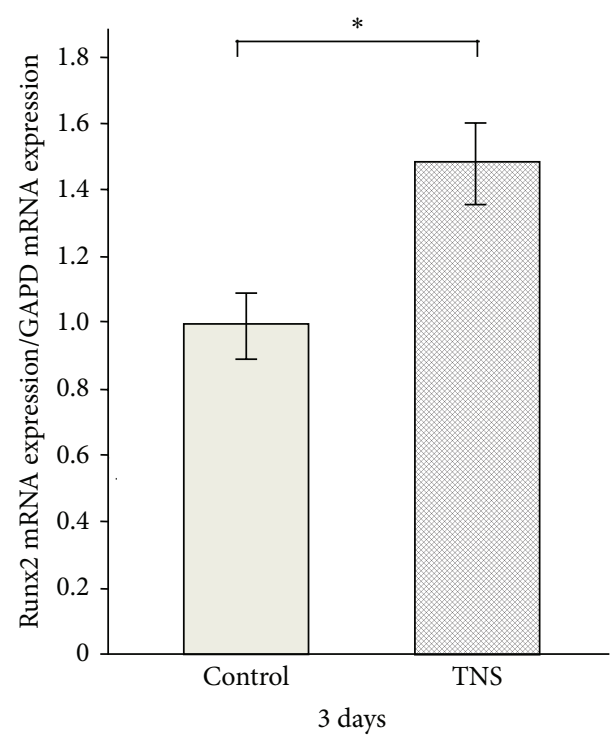

FIgURE 9: Expression of Runx-2 mRNA after 3 days of culture on treated (TNS) and control titanium alloy samples. There was a significant difference between the TNS and control groups after 3 days of culture $(P<0.05)$.

$\mathrm{Al}$ and $\mathrm{V}$ during $\mathrm{NaOH}$ treatment; no $\mathrm{V}$ was detected on the modified surfaces of treated alloy disks, whereas the contents of $\mathrm{Ti}, \mathrm{Na}$, and $\mathrm{O}$ were barely affected by alkali treatment. Our research revealed that $\mathrm{NaOH}$ treatment led to the formation of a Ti-O-Na titanate layer on the titanium surface. $\mathrm{V}$ is known to exhibit biological toxicity, so it is interesting that no $\mathrm{V}$ was detected in the test group. It is considered that $\mathrm{NaOH}$ treatment caused a thick oxide film to form on the $\mathrm{TiO}_{2}$ layer on the titanium alloy surface.

All implant surfaces are immediately covered with a layer of protein from the in vitro culture medium or in vivo biological fluids, and this interface modulates the cascade of cellular responses and behavior [26]. To examine the relationship between implant surface properties, opsonization, and phagocytosis under in vivo conditions, phagocytic experiments were conducted using a cell line in a cell culture medium that was supplemented with serum albumin and human opsonizing serum factors [27]. Albumin is the most abundant plasma protein and is known to discourage the adsorption of proteins that may stimulate inflammation and bacterial colonization [28]. In this study, adsorption of albumin by the test group was higher than that by the control group. The improvement of surface topography could be indirect; the adsorption of proteins or ions might act as a bridge between the nanostructured surface and cells.

Our results are the first comparison of RBM cell proliferation on TNS-modified titanium alloy surfaces with that on unprocessed controls. Surfaces with nanostructures are well known to possess increased surface area compared with those without such features $[9,29,30]$. This 

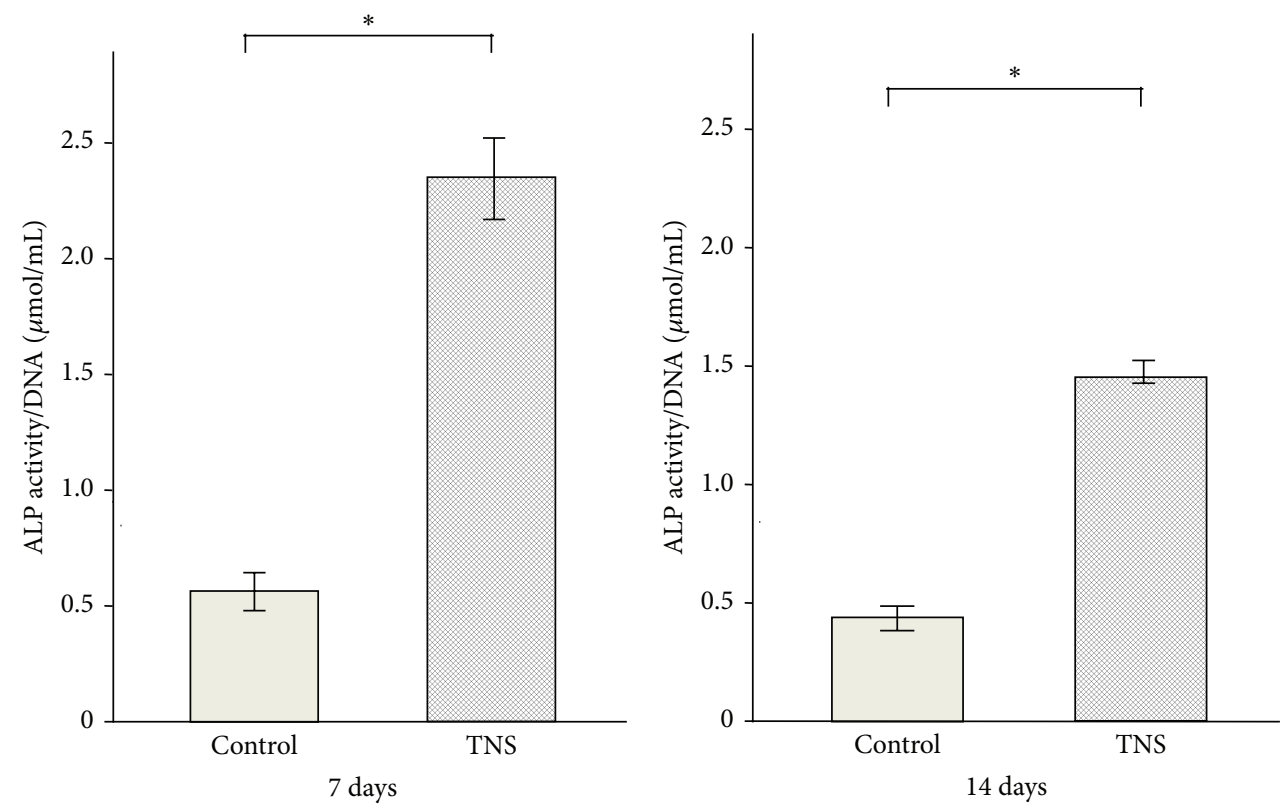

Figure 10: ALP activity after 7 and 14 days of culture on treated (TNS) and control titanium alloy samples. After 7 and 14 days, the ALP activity was expressed at significantly higher levels in the cells of the TNS samples compared with that of the control sample $(P<0.05)$.
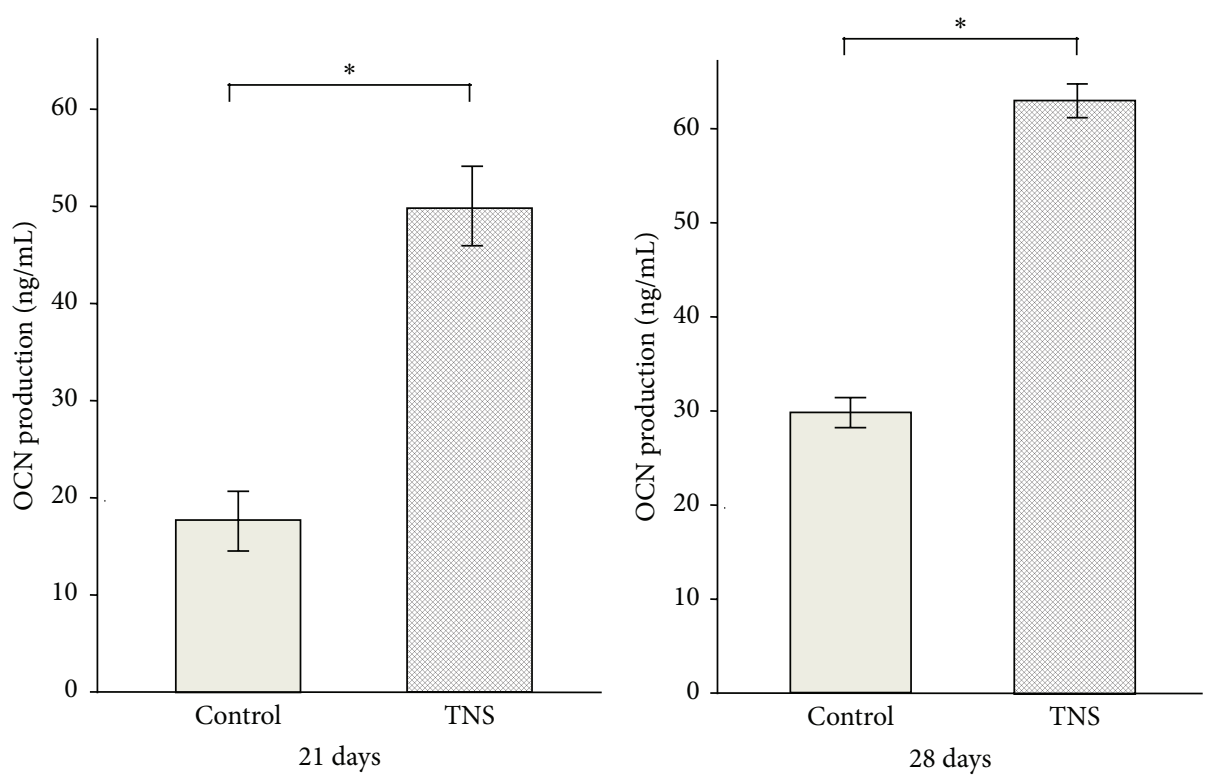

FIGURE 11: Osteocalcin production after 21 and 28 days of culture on treated (TNS) and control titanium alloy samples. The production of osteocalcin by cells of the TNS sample after 21 and 28 days was significantly higher than the cells of the control sample $(P<0.05)$.

increased surface area allows increased adhesion of cells such as osteoblasts and fibroblasts. Thus, the altered surface energies of materials with nanostructures have been suggested to promote tissue growth because of increased adsorption of select proteins compared with materials with microscale features [31]. Adsorption of select proteins can subsequently guide the adhesion of cells on the implant material surface, among other functions. Numerous studies have demonstrated improved cell adhesion and proliferation on nanostructured surfaces that could be beneficial for various tissue applications, including bladder, bone, vasculature, and nervous systems [32-34]. A previous study indicated that TNSs on titanium surfaces helped to regulate the osteoblastic differentiation of bone marrow cells and enhance mineralization. In the present study, the TNSs formed nanonodules with a diameter of about $19 \mathrm{~nm}$ on the titanium surfaces, and these structures promoted the adhesion and/or proliferation of cells. The network structure of TNS on titanium alloy 

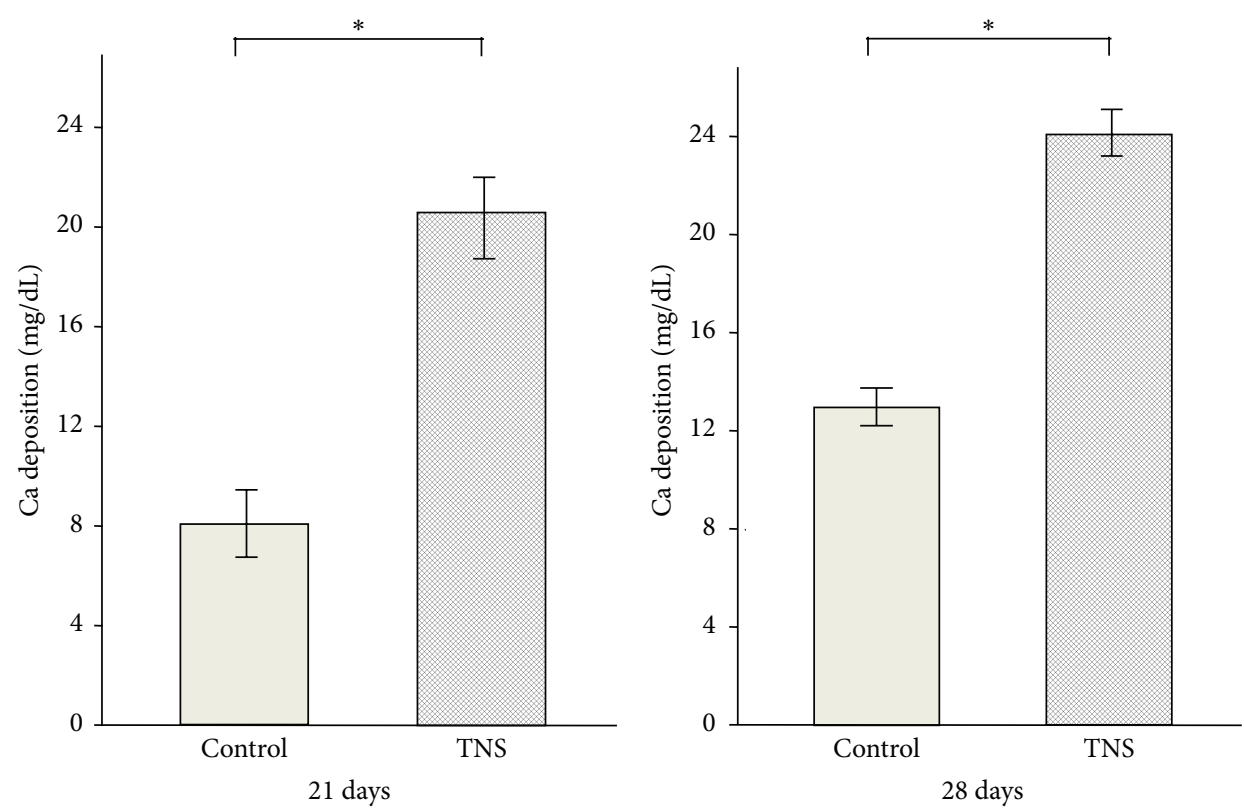

FIgURE 12: Calcium production after 21 and 28 days on treated (TNS) and control titanium alloy samples. The production of calcium by cells of the TNS sample after 21 and 28 days was significantly higher than that of cells of the control sample $(P<0.05)$.

facilitates rapid cell adhesion, spreading, and proliferation because of the mechanics of the TNS structure and chemical nature of the Ti-O-Na layer.

PCR analyses for the most specific and common markers of osteogenic induction were performed on RBM cells grown on treated and untreated titanium alloy implant materials. Different surface nanotopographies can alter the expression of important osteogenic regulatory genes such as Runx2. Runx2 mediates several early osteogenic gene responses for cellular adhesion [35]. Several trails of evidence show that surface modification leads to high expression of Runx2 mRNA [35-37]. The data from this study suggests that the elevated Runx2 mRNA expression in cells grown on the nanostructured titanium alloy surfaces compared with that on untreated surfaces is a causative factor in the differentiation of RBM cells into osteogenic cells.

ALP activity, OCN production, and calcium deposition were all elevated by the presence of TNSs on the implant surface. Importantly, the functional phenotypes expressed in the middle and late stages of culture, such as ALP activity and mineralization, were considerably increased. Substantial research has confirmed the ALP activation effect of surfacemodified materials [14, 38-40]. Surface modification of implants has been found to affect ALP activation [14, 41, 42]; our results also support this conclusion. The observed increase of OCN production in the presence of a nanostructured surface is also in agreement with previous findings $[14,43]$.

Titanium and titanium alloy implants have become an essential treatment modality in reconstructive surgery in orthopedics and dentistry. However, patient morbidity and treatment complications need to be minimized, and outcome predictability and treatment indications should be maximized. Therefore, considerable effort has been expended to developing new technologies to modify the surface of titanium to assist biointegration with bone [39]. The surfacemodification method used here is effective and simple, involving incubation in $\mathrm{NaOH}$ at room temperature without a template [13]. The resulting TNS-modified titanium surfaces induce RBM cell bone differentiation.

\section{Conclusion}

In conclusion, our investigation of different implant surface nanostructures demonstrated that modifying the implant surface at the nanoscale leads to the regulation of osteogenic differentiation of bone marrow cells and enhances mineralization of the surface of titanium alloy. Further development of advanced implant materials using nanotechnology should improve their osseointegration.

\section{Conflict of Interests}

The authors declare that there is no conflict of interests regarding the publication of this paper.

\section{Acknowledgments}

The authors thank Dr. Tohru Sekino from Tohoku University for making the nanosheets and for helpful suggestions. They also thank Professor Masahiro Tanaka and Dr. Hisataka Nishida for their encouragement and helpful suggestions. They are grateful to the members of the Department of Removable Prosthodontics and Occlusion and Department of Periodontology for their kind advice and assistance. This study was partly supported by an Oral Implant Research Grant (14-3) from Osaka Dental University and a Grant-inAid for Scientific Research $(24592942,26861664)$ from the Japan Society for the Promotion of Science. 


\section{References}

[1] M. Wadamoto, Y. Akagawa, Y. Sato, and T. Kubo, "The threedimensional bone interface of an osseointegrated implant. I: a morphometric evaluation in initial healing," Journal of Prosthetic Dentistry, vol. 76, no. 2, pp. 170-175, 1996.

[2] M. Vandrovcová and L. Bačáková, "Adhesion, growth and differentiation of osteoblasts on surface-modified materials developed for bone implants," Physiological Research, vol. 60, no. 3, pp. 403-417, 2011.

[3] B. D. Boyan, T. W. Hummert, D. D. Dean, and Z. Schwartz, "Role of material surfaces in regulating bone and cartilage cell response," Biomaterials, vol. 17, no. 2, pp. 137-146, 1996.

[4] Z. Schwartz, C. H. Lohmann, J. Oefinger, L. F. Bonewald, D. D. Dean, and B. D. Boyan, "Implant surface characteristics modulate differentiation behavior of cells in the osteoblastic lineage," Advances in Dental Research, vol. 13, pp. 38-48, 1999.

[5] K. Takeuchi, L. Saruwatari, H. K. Nakamura, J. M. Yang, and T. Ogawa, "Enhanced intrinsic biomechanical properties of osteoblastic mineralized tissue on roughened titanium surface," Journal of Biomedical Materials Research. Part A, vol. 72, no. 3, pp. 296-305, 2005.

[6] T. Ogawa, S. Ozawa, J.-H. Shih et al., "Biomechanical evaluation of osseous implants having different surface topographies in rats," Journal of Dental Research, vol. 79, no. 11, pp. 1857-1863, 2000.

[7] T. Ogawa and I. Nishimura, "Different bone integration profiles of turned and acid-etched implants associated with modulated expression of extracellular matrix genes," International Journal of Oral \& Maxillofacial Implants, vol. 18, no. 2, pp. 200-210, 2003.

[8] L. F. Cooper, T. Masuda, P. K. Yliheikkilä, and D. A. Felton, "Generalizations regarding the process and phenomenon of osseointegration . Part II. In vitro studies," International Journal of Oral and Maxillofacial Implants, vol. 13, no. 2, pp. 163-174, 1998.

[9] T. J. Webster and J. U. Ejiofor, "Increased osteoblast adhesion on nanophase metals: $\mathrm{Ti}, \mathrm{Ti}_{6} \mathrm{Al}_{4} \mathrm{~V}$, and CoCrMo," Biomaterials, vol. 25, no. 19, pp. 4731-4739, 2004.

[10] L. Marinucci, S. Balloni, E. Becchetti et al., "Effect of titanium surface roughness on human osteoblast proliferation and gene expression in vitro," The International Journal of Oral \& Maxillofacial Implants, vol. 21, no. 5, pp. 719-725, 2006.

[11] S. Oh, K. S. Brammer, Y. S. J. Li et al., "Stem cell fate dictated solely by altered nanotube dimension," Proceedings of the National Academy of Sciences of the United States of America, vol. 106, no. 7, pp. 2130-2135, 2009.

[12] T. Kasuga, M. Hiramatsu, A. Hoson, T. Sekino, and K. Niihara, "Titania nanotubes prepared by chemical processing," Advanced Materials, vol. 11, no. 15, pp. 1307-1311, 1999.

[13] S. Komasa, Y. Taguchi, H. Nishida, M. Tanaka, and T. Kawazoe, "Bioactivity of nanostructure on titanium surface modified by chemical processing at room temperature," Journal of Prosthodontic Research, vol. 56, no. 3, pp. 170-177, 2012.

[14] V. Perla and T. J. Webster, "Better osteoblast adhesion on nanoparticulate selenium-a promising orthopedic implant material," Journal of Biomedical Materials Research Part A, vol. 75, no. 2, pp. 356-364, 2005.

[15] T. Albrektsson, P. I. Branemark, and H. A. Hansson, "The interface zone of inorganic implants in vivo: titanium implants in bone," Annals of Biomedical Engineering, vol. 11, no. 1, pp. 1-27, 1983.
[16] H. M. Kim, F. Miyaji, T. Kokubo, and T. Nakamura, "Preparation of bioactive $\mathrm{Ti}$ and its alloys via simple chemical surface treatment," Journal of Biomedical Materials Research, vol. 32, pp. 409-417, 1996.

[17] K. J. Livak and T. D. Schmittgen, "Analysis of relative gene expression data using real-time quantitative PCR and the $2^{-\triangle \Delta C_{T}}$ method," Methods, vol. 25, no. 4, pp. 402-408, 2001.

[18] G. Mendonça, D. B. S. Mendonça, F. J. L. Aragão, and L. F. Cooper, "Advancing dental implant surface technology-from micron- to nanotopography," Biomaterials, vol. 29, no. 28, pp. 3822-3835, 2008.

[19] B. F. Bell, M. Schuler, S. Tosatti, M. Textor, Z. Schwartz, and B. D. Boyan, "Osteoblast response to titanium surfaces functionalized with extracellular matrix peptide biomimetics," Clinical Oral Implants Research, vol. 22, no. 8, pp. 865-872, 2011.

[20] T. Albrektsson, P. I. Branemark, H.-A. Hansson, and J. Lindstrom, "Osseointegrated titanium implants: requirements for ensuring a long-lasting, direct bone-to-implant anchorage in man," Acta Orthopaedica Scandinavica, vol. 52, no. 2, pp. 155170, 1981.

[21] R. E. Baier, A. E. Meyer, and J. R. Natiella, "Surface properties determine bioadhesive outcomes: methods and results," Journal of Biomedical Materials Research, vol. 18, no. 4, pp. 337-355, 1984.

[22] B. D. Boyan, L. F. Bonewald, E. P. Paschalis et al., "Osteoblastmediated mineral deposition in culture is dependent on surface microtopography," Calcified Tissue International, vol. 71, no. 6, pp. 519-529, 2002.

[23] H. Xing, S. Komasa, Y. Taguchi, T. Sekino, and J. Okazaki, "Osteogenic activity of titanium surfaces with nanonetwork structures," International Journal of Nanomedicine, vol. 9, no. 1, pp. 1741-1755, 2014.

[24] T. Fujino, Y. Taguchi, S. Komasa, T. Sekino, and M. Tanaka, "Cell differentiation on nanoscale features of a titanium surface: effects of deposition time in $\mathrm{NaOH}$ solution," Journal of Hard Tissue Biology, vol. 23, no. 1, pp. 63-69, 2014.

[25] L. Zhao, S. Mei, P. K. Chu, Y. Zhang, and Z. Wu, “The influence of hierarchical hybrid micro/nano-textured titanium surface with titania nanotubes on osteoblast functions," Biomaterials, vol. 31, no. 19, pp. 5072-5082, 2010.

[26] M. Roser, D. Fischer, and T. Kissel, "Surface-modified biodegradable albumin nano- and microspheres. II: effect of surface charges on in vitro phagocytosis and biodistribution in rats," European Journal of Pharmaceutics and Biopharmaceutics, vol. 46, no. 3, pp. 255-263, 1998.

[27] P. Roach, D. Farrar, and C. C. Perry, "Interpretation of protein adsorption: surface-induced conformational changes," Journal of the American Chemical Society, vol. 127, no. 22, pp. 8168-8173, 2005.

[28] C. D. McFarland, C. de Filippis, M. Jenkins et al., "Albuminbinding surfaces: in vitro activity," Journal of Biomaterials Science: Polymer, vol. 9, no. 11, pp. 1227-1239, 1998.

[29] G. Mendonça, D. B. S. Mendonça, F. J. L. Aragão, and L. F. Cooper, "The combination of micron and nanotopography by $\mathrm{H}_{2} \mathrm{SO}_{4} / \mathrm{H}_{2} \mathrm{O}_{2}$ treatment and its effects on osteoblast-specific gene expression of hMSCs," Journal of Biomedical Materials Research A, vol. 94, no. 1, pp. 169-179, 2010.

[30] K. Anselme, “Osteoblast adhesion on biomaterials," Biomaterials, vol. 21, no. 7, pp. 667-681, 2000.

[31] G. Balasundaram and T. J. Webster, "An overview of nanopolymers for orthopedic applications," Macromolecular Bioscience, vol. 7, no. 5, pp. 635-642, 2007. 
[32] R. L. Price, K. Ellison, K. M. Haberstroh, and T. J. Webster, "Nanometer surface roughness increases select osteoblast adhesion on carbon nanofiber compacts," Journal of Biomedical Materials Research Part A, vol. 70, no. 1, pp. 129-138, 2004.

[33] R. Langer and D. A. Tirrell, "Designing materials for biology and medicine," Nature, vol. 428, no. 6982, pp. 487-492, 2004.

[34] L. Zhang and T. J. Webster, "Nanotechnology and nanomaterials: promises for improved tissue regeneration," Nano Today, vol. 4, no. 1, pp. 66-80, 2009.

[35] M. O. Klein, A. Bijelic, T. Ziebart et al., "Submicron scale-structured hydrophilic titanium surfaces promote early osteogenic gene response for cell adhesion and cell differentiation," Clinical Implant Dentistry and Related Research, vol. 15, no. 2, pp. 166175, 2013.

[36] C. Masaki, G. B. Schneider, R. Zaharias, D. Seabold, and C. Stanford, "Effects of implant surface microtopography on osteoblast gene expression," Clinical Oral Implants Research, vol. 16, no. 6, pp. 650-656, 2005.

[37] G. B. Schneider, H. Perinpanayagam, M. Clegg et al., "Implant surface roughness affects osteoblast gene expression," Journal of Dental Research, vol. 82, no. 5, pp. 372-376, 2003.

[38] W. Att, K. Kubo, M. Yamada, H. Maeda, and T. Ogawa, "Biomechanical properties of jaw periosteum-derived mineralized culture on different titanium topography," The International Journal of Oral \& Maxillofacial Implants, vol. 24, no. 5, pp. 831841, 2009.

[39] K. S. Brammer, C. Choi, C. J. Frandsen, S. Oh, G. Johnston, and $\mathrm{S}$. Jin, "Comparative cell behavior on carbon-coated $\mathrm{TiO}_{2}$ nanotube surfaces for osteoblasts vs. osteo-progenitor cells," Acta Biomaterialia, vol. 7, no. 6, pp. 2697-2703, 2011.

[40] A. Göransson, A. Arvidsson, F. Currie et al., "An in vitro comparison of possibly bioactive titanium implant surfaces," Journal of Biomedical Materials Research A, vol. 88, no. 4, pp. 1037-1047, 2009.

[41] F. Iwasa, N. Tsukimura, Y. Sugita et al., " $\mathrm{TiO}_{2}$ micro-nanohybrid surface to alleviate biological aging of UV-photofunctionalized titanium," International Journal of Nanomedicine, vol. 6, pp. 1327-1341, 2011.

[42] W.-Q. Yu, X.-Q. Jiang, F.-Q. Zhang, and L. Xu, "The effect of anatase $\mathrm{TiO}_{2}$ nanotube layers on MC3T3-E1 preosteoblast adhesion, proliferation, and differentiation," Journal of Biomedical Materials Research A, vol. 94, no. 4, pp. 1012-1022, 2010.

[43] M. J. Dalby, D. McCloy, M. Robertson et al., "Osteoprogenitor response to semi-ordered and random nanotopographies," Biomaterials, vol. 27, no. 15, pp. 2980-2987, 2006. 

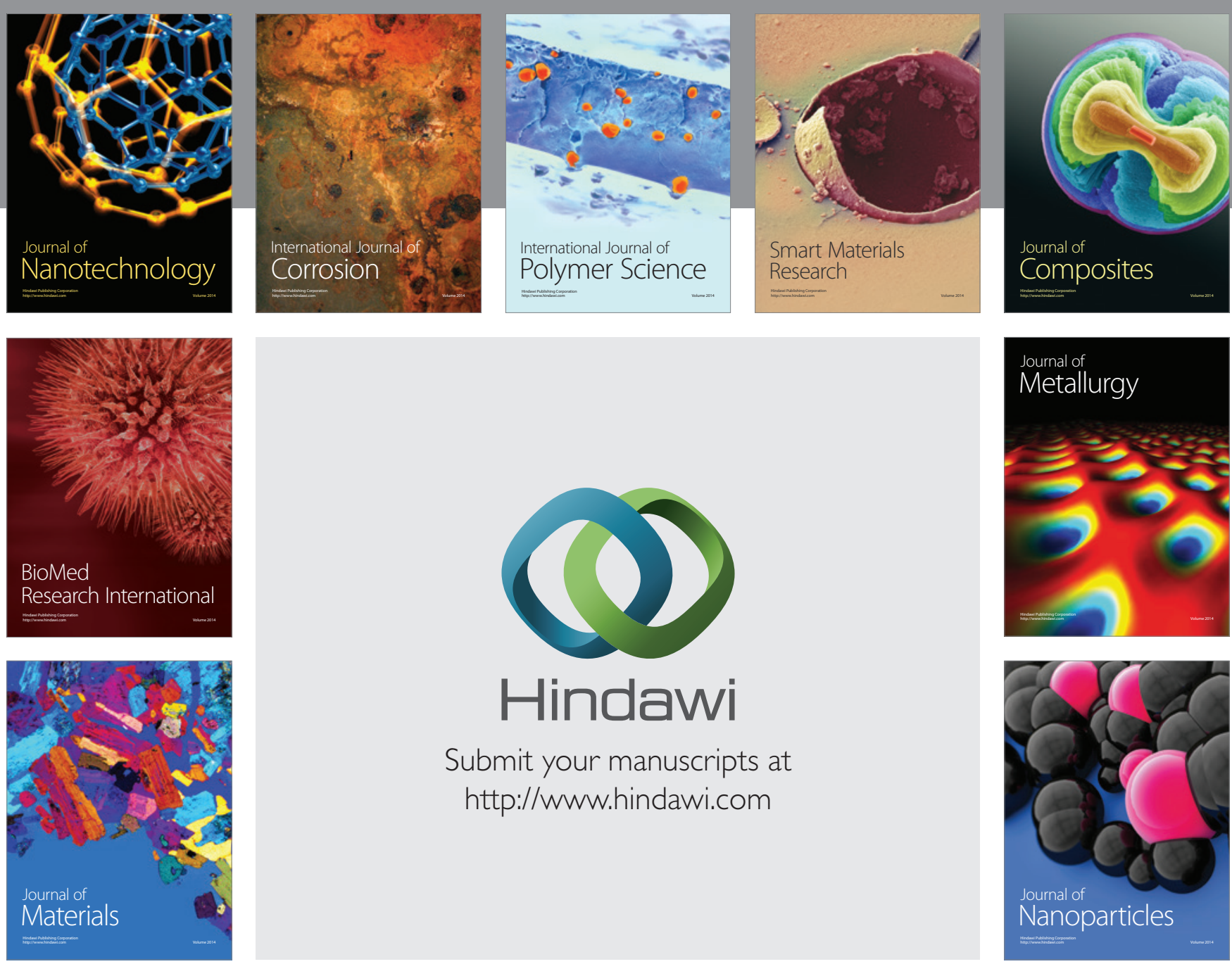

Submit your manuscripts at http://www.hindawi.com
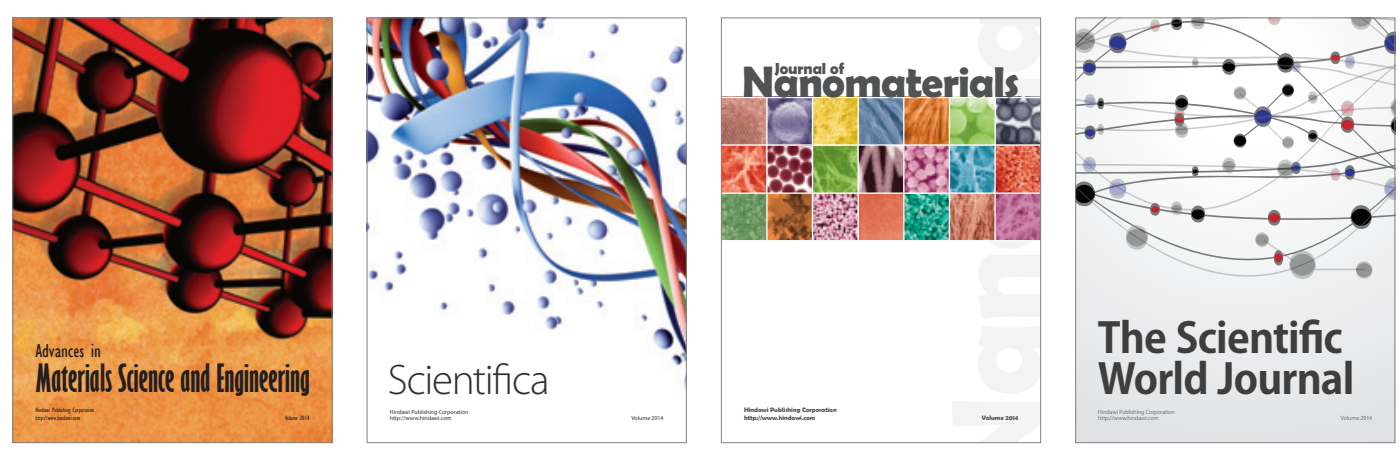

\section{The Scientific World Journal}
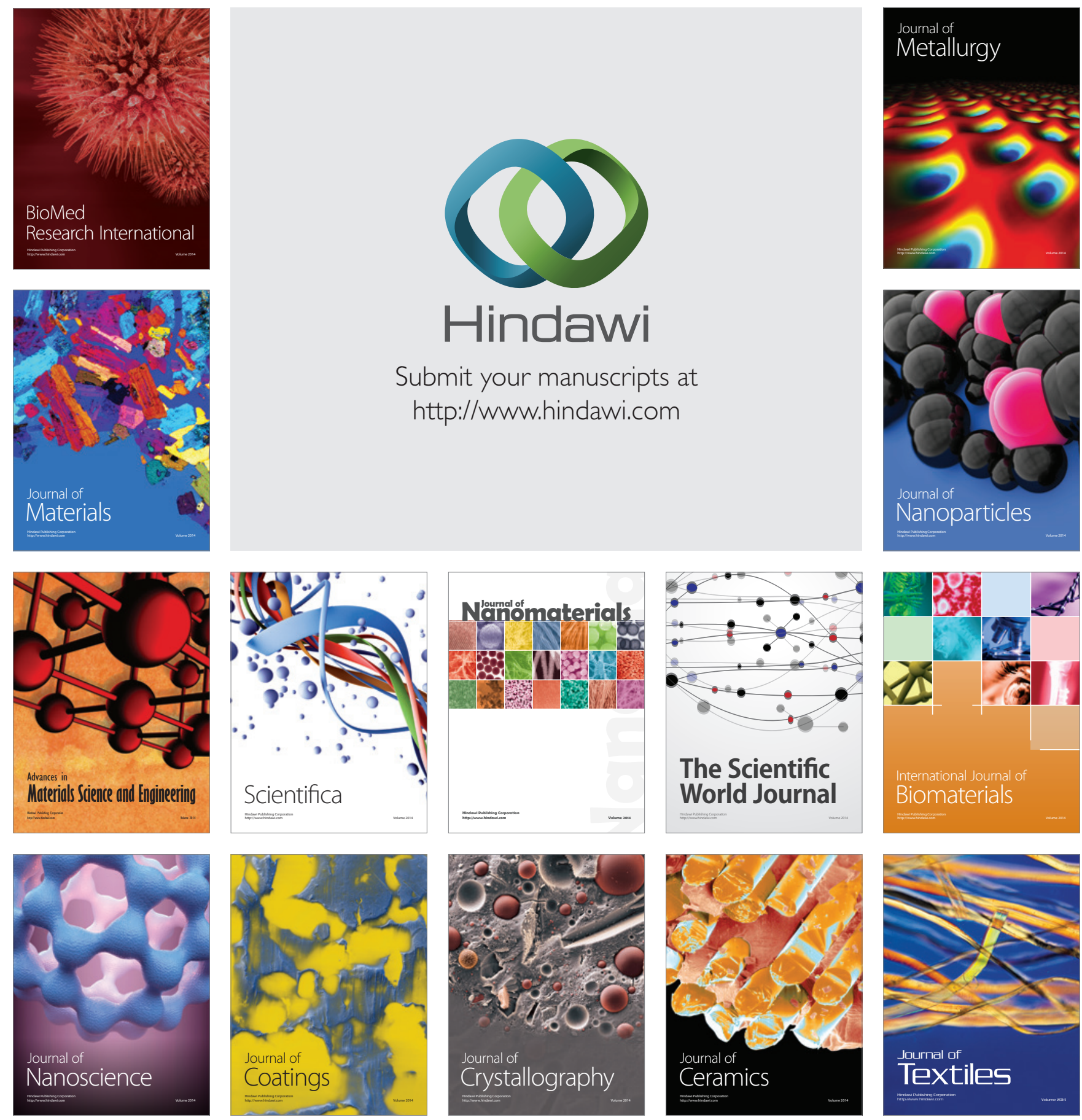